University of Nebraska - Lincoln

DigitalCommons@University of Nebraska - Lincoln

\title{
$5-2013$
}

\section{The limits to complexity: A thermodynamic history of bioenergy}

Adam J. Liska

University of Nebraska-Lincoln, aliska2@unl.edu

Casey D. Heier

University of Nebraska-Lincoln, cheier5@stanford.edu

Follow this and additional works at: https://digitalcommons.unl.edu/bseliska

Liska, Adam J. and Heier, Casey D., "The limits to complexity: A thermodynamic history of bioenergy" (2013). Adam Liska Papers. 15.

https://digitalcommons.unl.edu/bseliska/15

This Article is brought to you for free and open access by the Biological Systems Engineering at DigitalCommons@University of Nebraska - Lincoln. It has been accepted for inclusion in Adam Liska Papers by an authorized administrator of DigitalCommons@University of Nebraska - Lincoln. 


\title{
The limits to complexity:
}

\section{A thermodynamic history of bioenergy}

\author{
Adam J. Liska and Casey D. Heier \\ University of Nebraska-Lincoln, Lincoln, NE, USA \\ Corresponding author - Adam J. Liska, Department of Biological Systems Engineering, University of Nebraska-Lincoln, \\ 203 L.W. Chase Hall, Lincoln, NE 68583-0726 USA; email aliska2@unl.edu
}

\begin{abstract}
The history of civilization is biased toward the use of bioenergy because of the biophysics of life and the structure of our natural environment. Energy physically drives the creation and maintenance of complex systems, which is shown here from simple molecular structures to empires. Only a fraction of the complexity currently supported by fossil fuels can be maintained using the energy in plant biomass alone, which is limited by global net primary productivity. From the dawn of civilization, agricultural land has always been used for energy for transportation, via feed for animals, and there has always been a trade-off between "food, fuel, and environment." The United States (USA), Germany, and Brazil now use roughly $12 \%$ of agricultural land for biofuels, but energy efficiency improvements by 2050 could require only $11 \%$ of US agricultural land or $15 \%$ of forest land for biofuels to support all modes of US transportation. Despite its limitations, bioenergy has been extensively used for thousands of years and probability theory suggests it will continue to be a critical energy resource.
\end{abstract}

Keywords: agriculture, biofuel, complexity, energy, oil, thermodynamics

\section{Introduction}

$\mathrm{T}$ he complexity of human society has always been limited by available energy. For more than 10,000 years, the foundation of society has been bioenergy in the form of grass, crops, and trees for food for humans and other animals, as well as being a source of heat. ${ }^{1,2}$ Over the last 800 years, modern global society has established itself using bioenergy and then diverged away from it to predominantly use coal and then oil. Fossil fuels have supported extensive increases in the complexity of society, but they have also been associated with a number of increasing costs from imported foreign oil and climate change, among other issues. ${ }^{3,4}$ The costs and risks from fossil fuels have recently prompted policymakers globally to exploit a greater fraction of domestic bioenergy potential. ${ }^{5}$ Yet, to have realistic expectations for the complexity of society and successfully adapt to the limitations of bioenergy, a clear understanding of the fundamental physical laws that make energy essential for sustaining complexity is needed, as well as a global historical perspective to provide a reliable guide for predicting future long-term energy trends.

\section{Energy drives complexity}

Thermodynamics is concerned with the limits of available energy to produce order. ${ }^{6}$ The second law of thermodynamics states that the natural direction of change in all physical systems is toward increasing disorder yet ordered structures exist at a large range of spatial and temporal scales. ${ }^{7}$ In a gas isolated from outside energy, atoms and molecules move randomly and collide with one another in a system lacking or- 
der. When energy enters this gas in the form of heat (e.g. from burning biomass), trillions of atoms self-organize like a school of fish and move in the coherent patterns of fluid dynamics (Figure 1a). ${ }^{8,9,10}$ The ordered energy in a system that is available to do maximum work on its environment has been defined as free energy $y^{6-8,11}$ (oft en alternatively defined as exergy ${ }^{12}$ ). From fluids to organisms to empires, local order arises in far-fromequilibrium open systems from inputs of free energy, thus counteracting the natural pull toward disorder described by the second law of thermodynamics. ${ }^{6-8}$

The evolution of energy and matter in the universe has produced a spectrum of ordered structures that have emerged over billions of years, from galaxies to planets to organisms and empires. Far-reaching insight into the general evolution of all forms of complex sys- tems shows that higher rates of energy conversions are generally needed to support greater complexity. ${ }^{8}$ Each more complex class of structure has been shown to convert roughly ten times more free energy per second per unit of mass (e.g. power per gram) (Figure 2a). These structures also build on top of one another in a hierarchy to produce more complexity, such as proteins must first be assembled to build living organisms, to then build society. In addition to the use of measurements of free energy rate densities, other methods have also been developed to measure complexity. ${ }^{13}$

For ordered life on the Earth's surface, free energy in the Sun's radiation is transformed in plants into complex biochemical polymers such as cellulose, using photosynthetic chemical reactions that organize millions of atoms in the process. The energy in sugar

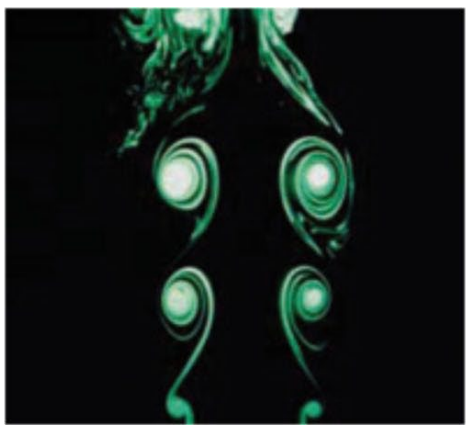

(a)

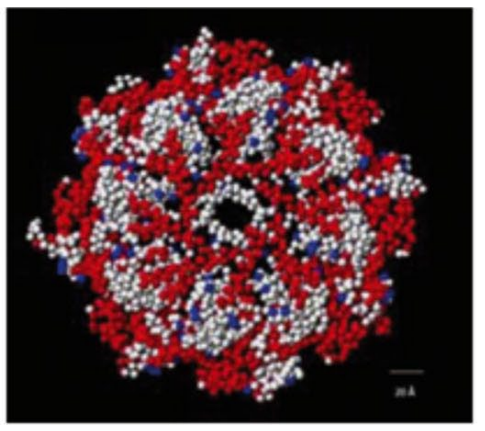

(b)

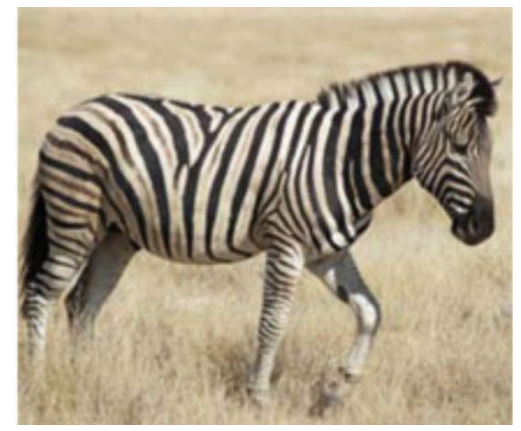

(c)

Figure 1. Ordered atoms from energy transformations: (a) fluid motion of heated smoke from burning biomass (cigar), 0.01 liters air, $\sim 6 \times 10^{20}$ particles, (b) chaperonin protein from cattle, ${ }^{52}$ Bos taurus, 6.6787 $\times 10^{4}$ atoms, and (c) Zebra, Equus sp., wild relative to the horse, $3.9 \times 10^{28}$ atoms. Sources: Samimy et al., ${ }^{10}$ Protein Data Bank, ${ }^{52}$ http://www.rcsb.org/, and Wikimedia Commons.
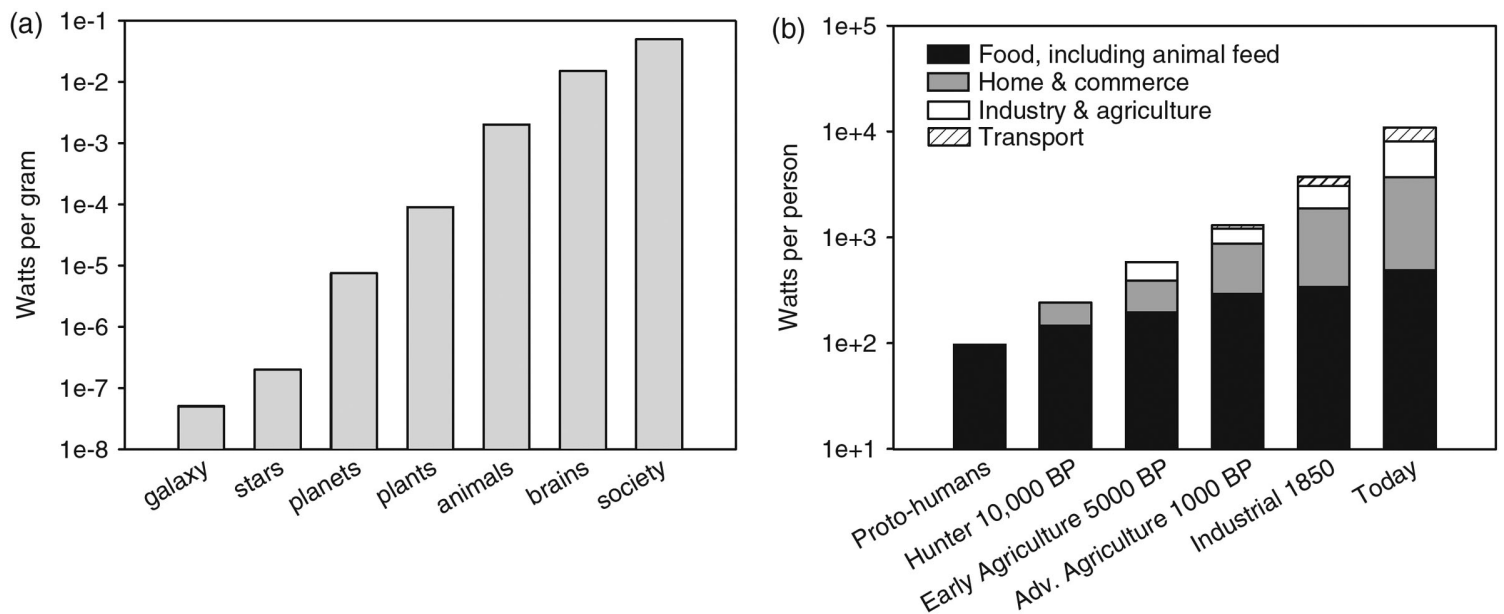

Figure 2. Increasing rates of energy transformations and complexity in nature and society (log scales): (a) energy conversion per time and mass for complex systems, ${ }^{8}$ (b) energy use at different stages of human history. ${ }^{19}$ 
("biofuels") in organisms is then transferred in chemical synthesis reactions to organize tens of thousands of atoms, producing other complex molecules like proteins (Figure $1 \mathrm{~b}$ ). ${ }^{9}$ Within a single cell containing millions of proteins, trillions of atoms become organized by conversion of biomass energy (throughout this review, bioenergy, biomass, and biofuels are assumed synonymous because they all denote limited chemical energy in various forms that can be used in a multitude of processes).

Plant biomass has provided energy for the evolution of herbivores from single-celled fungi to insects to much larger-hooved quadrupeds. Organisms evolve by increasing body size (Cope's rule) to access and store more chemical energy, and by diverging into structurally efficient specialized forms to acquire limited energy from external niches (e.g. adapted bird beaks for extracting energy from different plant seeds). ${ }^{14,15}$ The second law of thermodynamics ensures the majority of the stock of free energy in plants is eventually lost as unusable heat when it is eaten by animals and converted to internal metabolism (thermal energy) and animal locomotion (kinetic energy). This loss of free energy as heat then reduces the free energy available for large predators (e.g. lions and humans) and explains why big fierce animals are so scarce in nature: there is not enough energy to maintain numerous copies of their complex structures. ${ }^{15}$ The limited complexity in nature provides a reference for understanding why very large human populations are improbable from a long-term thermodynamic perspective, because maintaining them requires enormous amounts of energy. The mass of humanity (containing 55 million tons of carbon) is now roughly 10 times larger than the mass of all other terrestrial wild mammals on Earth, excluding domestic animals and livestock. ${ }^{2}$
An average Mongolian horse weighing $400 \mathrm{~kg}^{16}$ consumes 77 megajoules (MJ) of biomass energy per day $^{1}$ to maintain its efficient and coherently organized atomic structure. Assuming a similar tissue composition as humans containing oxygen $(61 \%)$, carbon $(23 \%)$, hydrogen $(10 \%)$, nitrogen $(2.6 \%)$, calcium $(1.4 \%)$, and phosphorus (1.1\%), ${ }^{17}$ a horse is calculated here to contain about 39,000 trillion trillion atoms $\left(3.9 \times 10^{28}\right)$ organized into a coherent complex organism (Figure 1c). If a horse were unable to feed on the free energy in grass, this organism would rapidly lose its order (e.g. die) and its atoms would diffuse randomly into the atmosphere according to the second law of thermodynamics (during the thermodynamically spontaneous oxidation of biopolymers, Gibbs free energy decreases and entropy increases ${ }^{18}$ ).

By the same physical laws that act in fluid motion and in organisms, the complexity of society (e.g. roughly measured as the number of subcomponents and interconnections) also increases in general with higher rates of free energy conversion per person. $8,19,20$ Progressive stages of human history have used exponentially increasing amounts of energy for food, material security and wellbeing, and transportation (Figure 2b). Life in a sod house in Nebraska, USA, in 1886 used immensely lower energy and exhibits great simplicity relative to modern life in a highly ordered city such as Hong Kong, China (Figure 3). But after the rate of energy transformations has increased and produced more complexity in society, related energy limitations and subsequent decreases in energy flows, efficiency gains aside, will ultimately lead to a loss of complexity (Figure 3c). ${ }^{21}$

The inescapable physical law that complexity requires transformations of free energy raises the importance of energy resources in the historical development

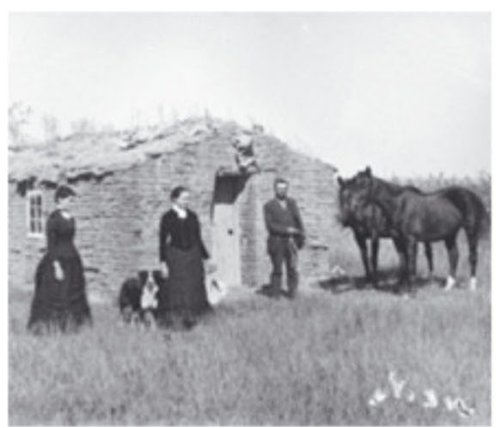

(a)

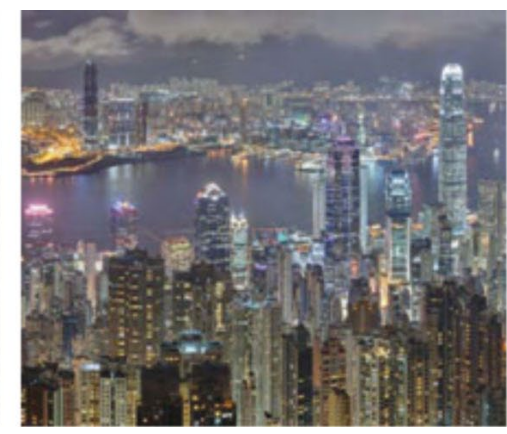

(b)

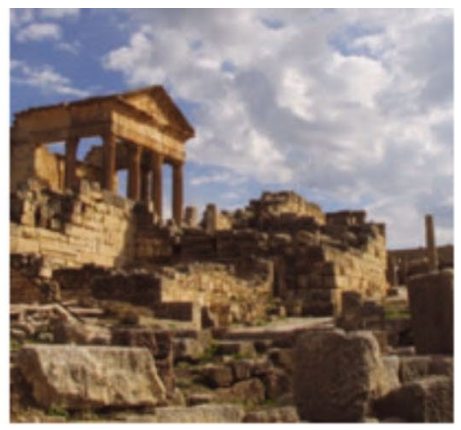

(c)

Figure 3. Energy transformations and complexity in society: (a) low energy society based on biomass in Nebraska, USA, 1886, (b) complexity sustained by high rates of energy flows in Hong Kong, China, and (c) Roman ruin in North Africa after energy flows have been withdrawn. Sources: S.D. Butcher, US Library of Congress, and Wikimedia Commons. 
of society. Just as organisms capture limited energy to drive their complexity, society captures limited energy from the environment to maintain its own complexity. In a further corollary, the general recurring thermodynamic efficiency of living forms has enabled them to survive for millions of years. In considering the future design of society, adaptations using similar levels of energy efficiency are likely to increase the long-term stability of society.

\section{Energy resources and empires throughout history}

Building on biological complexity, the horse was the vehicle and biomass was the energy resource to create and maintain the largest pastoral land empire in history. The Mongol empire (1206-1368) controlled nearly all of Asia and Eastern Europe using roughly 800,000 horses in a pastoral empire based on limited bioenergy. ${ }^{22}$ With an average moderate metabolism rate of $77 \mathrm{MJ}$ per day, the total energy used for herding and trade to maintain the Mongol empire was roughly 23 petajoules $\left(2.3 \times 10^{16}\right.$ joules) per year at its peak (Figure 4 ). The Internet of the age was composed of 50,000 horses to move information across the empire. ${ }^{23}$

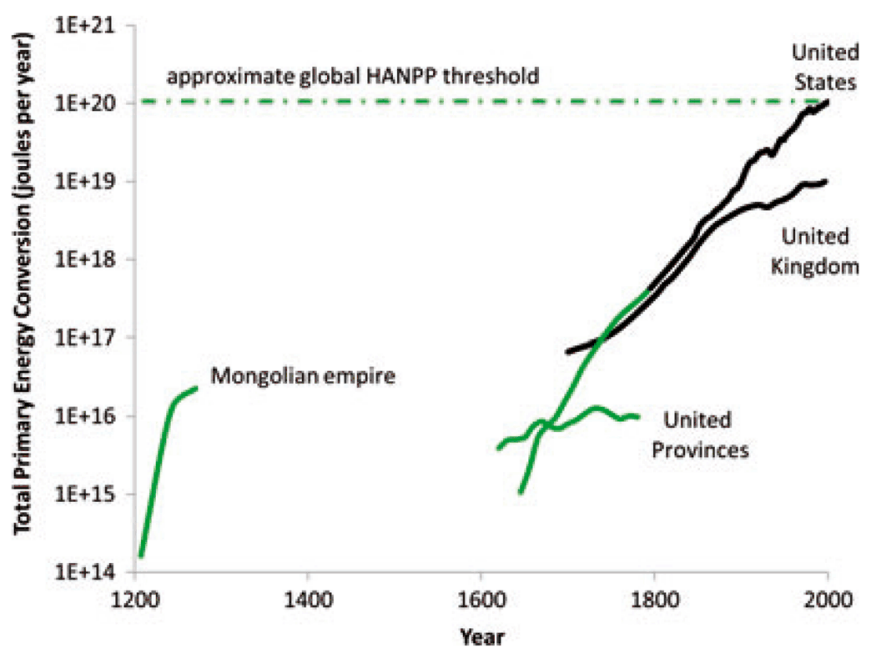

Figure 4. Eight hundred years of increasing rates of energy conversions (log scale) in successive global empires and an approximate HANPP threshold. Fossil energy (black) and bioenergy (green) are shown. Mongol empire energy use (horse feed) over time was assumed proportional to land area. ${ }^{53}$ United Provinces energy use over time was assumed proportional to out-bound fleets to the East Indies ${ }^{54}$ increased by 20 fold to account for the larger use of peat for fuel. ${ }^{1}$ The USA used nearly all bioenergy up to $1800 .^{26}$
Since the demise of the Mongol empire, three global empires have made use of different primary energy sources to create and sustain their global maritime trade networks and to counteract the tendency toward disorder. The United Provinces (Netherlands) in the seventeenth and eighteenth centuries relied on wind and biomass, the United Kingdom (British Empire) of the late nineteenth and early twentieth centuries relied on coal, and now the USA's global military and trade empire relies primarily on oil. ${ }^{24}$ Each successive empire used new innovations and increasing technological complexity to access larger energy resources and convert them to useful services at a faster rate (Figure 4).

By 1700, the Netherlands transformed roughly 0.0004 exajoules (EJ) of wind energy per year, with approximately $50 \%$ powering its navy built from trees and $50 \%$ powering its windmills (Figure 4); this was equivalent to $<5 \%$ of the massive amount of peat burned per year for heat which increased annual energy use to 0.008 EJ..$^{1}$ Roughly 240 years later, at the height of the next global maritime empire in 1940, Britain used 700 times more energy per year (5.4 EJ) from coal. ${ }^{25}$ Only 10 years later the next maritime power (USA) used nearly 37 EJ of energy annually, which increased to 105 EJ in 2008 (using coal, natural gas, oil) (Figure 4). ${ }^{26}$ Total energy use today by the leading military and trade empire is 13,000 times higher per year than by the Netherlands global empire in 1700 .

Each of these empires initially exploited available domestic energy resources, with the United Provinces, the United Kingdom, and the USA having abundant wind, coal, and oil resources for transportation systems, respectively. Oil fuels nearly all transportation in the USA, but with only 20.7 billion barrels of proven reserves, $98.7 \%$ of global oil reserves lie outside of the USA today. ${ }^{27}$ Because of the critical value of oil as a transportation fuel, $\sim 90 \%$ of the remaining proven global oil reserves have been nationalized. ${ }^{28}$ From 2007 to $2010,57 \%$ of US oil consumption came from imports averaging $\$ 263$ billion per year. ${ }^{26}$ Oil import costs are now contributing to debt in a number of countries ${ }^{29,30}$ and military activities related to trade routes further add to these costs. ${ }^{3}$

In addition, climate change from burning fossil fuels is projected to cost tens to hundreds of trillions of dollars globally by $2100 .{ }^{31}$ These costs will come from more intense droughts and floods, rising sea levels, increasing storm intensity, heat waves, other weather-related disruptions, and associated adaptation. ${ }^{4,31}$ As the complete costs of fossil fuels are accounted for, society will continue to rely on the widely available bioenergy resources that have fostered its development. 


\section{Bioenergy trade-offs, net primary produc- tivity, and future biofuel area}

Before becoming the foundation of the Mongol empire, the horse was first domesticated 6000 years ago in Asia as a food source and used soon after for transportation..$^{23}$ Thus from ancient times it is clear that use of limited biomass resources involved a trade-off between food and fuel, having either horse meat or transportation. Horse ancestors in North America became extinct 9000 years ago due to overhunting and climate change, but the horse was later brought back to North America in 1493 and after by European colonizers. ${ }^{23}$ By 1910 in the USA, $35-40 \%$ of agricultural land provided feed for horse power on farms (20-25\%) and for urban transportation (15\%), with an average daily diet of $1 \mathrm{~kg}$ oats, $2 \mathrm{~kg}$ corn grain, and $4.5 \mathrm{~kg}$ of hay per animal. ${ }^{1}$ Here again, people had to make a choice between having either food or fuel.

There are now 400 million draft animals used globally, including 58 million horses that are vital for farm power and transportation. ${ }^{32}$ Clearly people today are still involved in a trade-off between food and fuel, by either using livestock for meat or for transportation and crop production. Since the dawn of civilization and the domestication of the horse, agricultural land has always been used for energy for transportation: this is the normal order of human society.

In addition to transportation, human ancestors have controlled biomass fires for at least 790000 years. ${ }^{1}$ Since $1700, \sim 40 \%$ of global forests have been harvested for fuel, building material, and to increase energy harvests from agriculture. ${ }^{33}$ Fuelwood is now the primary energy source for heating and cooking for $\sim 2.6$ billion people ( $\sim 40 \%$ of global population) and contributes to $\sim 55 \%$ of global deforestation..$^{33}$ Society has always made tradeoffs between fuel and the environment and will continue to do so.

When contemplating the future design of society and the use of bioenergy, how long are these patterns likely to occur? The fundamental premise of probability is that the long-term patterns of the past will approximate the frequency of future events. ${ }^{34}$ Based on the biomass use described, there is a high probability that a measurable fraction of society will continue to burn biomass for transportation and power (primarily via animals). This proposition is also supported by the fact that, in general, processes that have a long duration in the past are likely to exist for a long time into the future, and those that have existed for shorter times are likely to have shorter futures. First published in $\mathrm{Na}$ ture in 1993, J.R. Gott developed a statistical theory to estimate the duration of processes based on the above idea, and his method has subsequently been shown to accurately predict the future duration of a range of sub- jects, including the lifetime of the Berlin Wall, the Soviet Union, world leaders, Broadway plays, the Titanic, and the Hindenburg airship. ${ }^{35,36}$

Based on Gott's method, if one assumes they are currently observing humanity at a random point over its entire duration of fire use (including future use), there is a $95 \%$ probability that biomass will be burned for energy for between 20,000 years $(790,000 \times 1 / 39)$ and 31 million years $(790,000 \times 39)$ into the future, based on past patterns. If only the higher levels of biomass use are considered since the expansion of agriculture and the building of the Pyramids of Egypt (4500 years ago), then there is a $95 \%$ probability of a similar level of use for roughly 120 to 180,000 years. All probabilities are conditional and more information could narrow the confidence intervals of these predictions, but this would likely make the prediction less reliable. ${ }^{37}$ When considering any practical design and management for the relevant future, historical trends and probability theory suggest that agricultural bioenergy for transportation and power will effectively always be an integral part of human society.

Global terrestrial net primary productivity (NPP) is the finite amount of free energy captured annually in biomass. Over the last 30 years, global NPP has been relatively constant at 53.6 Pg per year, with annual variability of only $2 \%$, although recent estimates have ranged from 48-65 Pg per year. ${ }^{2,38}$ In 2004, the highest regional Human Appropriation of NPP (HANPP) was estimated to be $80 \%$ in South Asia and $70 \%$ in Western Europe, while global HANPP was roughly 20\% (11.5 Pg of carbon). ${ }^{2}$ In 2000, global harvests of fuelwood and roundwood totaled roughly $6.9 \mathrm{Pg}$ of carbon (40 EJ), and comprised $\sim 10 \%$ of the $382 \mathrm{EJ}$ of global energy use (305 EJ from fossil fuels). ${ }^{2}$

With new satellite measurements and analysis, HANPP globally today is estimated at 38\% (20 Pg carbon), with $11 \%$ used for agriculture $(6 \mathrm{Pg}) .{ }^{38}$ Society is expected to be able to only access $10 \%$ more NPP (5 Pg) due to preserved land and carbon in roots. Higher rates of NPP use, however, have also been suggested as an indicator of the increasing environmental impacts of society, and higher use will clearly lead to degradation of the environment in many situations. ${ }^{20}$

With a hypothetical $25 \mathrm{Pg}$ carbon of HANPP ( 48\% NPP globally), roughly 145 EJ $\left(1.45 \times 10^{20}\right)$ of bioenergy could possibly be utilized for food, heating, materials, and transportation annually (Figure 4). Future NPP could be increased with improved water management, increasing atmospheric $\mathrm{CO}_{2}$ concentrations, and global warming adding to the total heat available for plant growth. But NPP growth could also be reduced by increasing droughts and increased plant and soil respiration, making future estimates of net changes in NPP highly uncertain. ${ }^{2}$ 
Table 1. Land area for biofuels in three countries on three continents in 2010.

\begin{tabular}{|c|c|c|c|}
\hline & United States & Germany & Brazil \\
\hline Crop area, arable land & 100\% (128 Mhat) & 100\% (11.9 Mha§) & 100\% (61.2 Mha§) \\
\hline Corn-ethanol & 9.9\% (12.7 Mhat) & - & - \\
\hline Sugarcane-ethanol & - & - & 7\% (4.3 Mhaף) \\
\hline Sugar beet/wheat-ethanol & - & $2 \%(0.24$ Mhao $)$ & - \\
\hline Soybean-biodiesel & 1.7\%(2.2 Mha $)$ & - & 5.1\% (3.1 Mha\#) \\
\hline Rapeseed-biodiesel & - & 7.6\% (0.91 Mhaœ) & - \\
\hline Corn/crops-biogas (heat/elec.) & - & 7.5\% (0.90 Mhaœ) & - \\
\hline Biofuel Area & $\mathbf{1 1 . 6 \%}$ (14.9 Mha) & $\begin{array}{l}9.6 \% \text { ( } 1.2 \mathrm{Mha}) \\
\text { total bioenergy } 17.2 \% \text { ( } 2.1 \mathrm{Mha})\end{array}$ & 12.1\% (7.4 Mha) \\
\hline
\end{tabular}

+13.3 billion gallons in 2010 at 411 liters per Mg corn grain, ${ }^{26} 39 \%$ of US corn production. ${ }^{26,55}$

₹ 343 million gallons ${ }^{26}$ at 205 liters per Mg soybean seed, ${ }_{1}^{5}$ 7\% of US soybean production..$^{26,55}$

$\S$ Crop area for $2009 .{ }^{56}$

$\infty$ Biofuels crops for 2011.57

I $55 \%$ of 7.8 Mha in 2010.50

\# 13\% of 23.5 Mha in $2010 .{ }^{50}$

As a fraction of HANPP, liquid biofuels based on crops (e.g. sugarcane, maize, and soybean), pasture (e.g. switchgrass), and forests are merely continuing the practices of thousands of years of using limited plant bioenergy for transportation. Today on three different continents, the USA, Brazil, and Germany have allocated $10-12 \%$ of crop area for biofuels (Table 1 ). The future duration of these practices can be estimated, but the higher NPP of the Tropics will always give this region a greater bias toward biofuels than temperate regions. Based on Gott's theory, ethanol industries that have endured since roughly 1977 in Brazil and the USA can be estimated to have a $50 \%$ probability of future duration of 12 to 100 years, with a $25 \%$ probability they will be obsolete in less than 12 years and a $25 \%$ probability they will be in use for more than 100 years. ${ }^{35}$

All forms of modern biofuels are obviously not equally efficient or environmentally benign, ${ }^{39}$ but their use is rational when balanced against the costs and risks from other energy sources at an appropriate level of demand. The renewable chemical energy in biomass can be stored as a solid, liquid, or gas and it generally does not contribute to climate change when burned. ${ }^{40}$ Use of biofuels can reduce net carbon emissions to the atmosphere (with appropriate land-use change management), ${ }^{41}$ reduce oil wars, spills, and imports, ${ }^{3}$ and foster global rural development for billions of people. On the other hand, biofuels from agricultural land do ultimately compete with food production (NPP is limited), thus increasing the risk of food shortages, if food production and use is not made more efficient. Biofuel production could also degrade the global ecosystem by depleting soil resources, increasing deforesta- tion and carbon emissions, and reducing biodiversity. ${ }^{33,39}$ It is clear that biofuels must be developed in such a way that limits the disruption of native ecosystems, such as relying on high yield crops, ${ }^{42,43}$ decaying forest resources (e.g. beetle-killed pine) ${ }^{44}$ and other high-density biomass.

Along with biofuel development, there is a global trend toward energy efficiency that could reduce US oil consumption, while still maintaining the services that oil provides. ${ }^{45}$ For example, countries like Japan and Germany already use roughly half of the energy per capita per year as the USA due to more efficient housing and transportation systems, but they still enjoy similar standards of living. ${ }^{1}$ Recent trends in energy efficiency are driven in part by energy price increases, but these trends also fundamentally mimic the thermodynamic efficiency of the structures of organisms for energy capture and conversion to useful work, as already discussed. A recent study estimated global energy use could be reduced by $73 \%$ by ultra-lighting and improved aerodynamics for vehicles, building insulation, and other techniques, with minimal loss of services. ${ }^{46}$ These improvements would reduce waste heat, reduce vehicle mass and the energy needed to overcome the force of gravity, and use more information in design. ${ }^{47}$ A practical efficiency plan indicates a possible $67 \%$ reduction of transportation energy use and carbon emissions for Munich, Germany, from 2008 to $2058 .{ }^{48}$ An example of a revolutionary improvement in transportation efficiency is the new diesel-electric hybrid two-seater car from Volkswagen that is $21 \%$ carbon fiber and gets 230 miles per gallon (mpg), and is expected be sold in Germany in $2013 .{ }^{49}$ 
Table 2. Estimated agricultural or forest land for US biofuel production for the transportation sector in 2050.

\begin{tabular}{|c|c|c|c|c|c|c|c|}
\hline Crop & Fuel & $\begin{array}{l}\text { Energy } \\
\text { density } \\
\mathrm{MJ} \mathrm{kg}^{-1}\end{array}$ & $\begin{array}{c}\text { Fuel } \\
\text { demand, } \\
10^{9} \mathrm{~kg} \mathrm{yr}^{-1}\end{array}$ & $\begin{array}{c}\text { Conversion } \\
\text { yield, } \\
\mathrm{kg} \mathrm{kg}^{-}\end{array}$ & $\begin{array}{c}\text { Feedstock } \\
\text { demand, } \\
10^{6} \mathrm{Mg} \mathrm{yr}^{-1}\end{array}$ & $\begin{array}{l}\text { Crop Yield,§ } \\
\mathrm{Mg} \mathrm{ha}^{-1} \mathrm{yr}^{-1}\end{array}$ & $\begin{array}{l}\text { Area } \\
\text { Mha* } \\
\text { (US \%) }\end{array}$ \\
\hline sweet sorghum & cellulosic ethanol & 27.0 & 256 & 0.593 & 432 & 30 & $14.4(11.2 \%)$ \\
\hline hard-wood & FT-biodiesel & 42.7 & 162 & 0.359 & 452 & 10 & $45.2(14.9 \%)$ \\
\hline
\end{tabular}

$+90 \%$ of maximum yield, Cherubini and Strømman. ${ }^{58}$

₹ 3.1 million barrels per day of oil equivalent ${ }^{49}$ at 6,119 MJ per barrel is $6.9 \times 10^{18}$ joules. $^{26}$

§ Short rotation coppice. ${ }^{41}$ Sweet sorghum (SS) grown across Nebraska had average yields of 26.3 (7.5-48) $\mathrm{Mg} \mathrm{ha}^{-1}$ $\mathrm{yr}^{-1}$ of dry aboveground biomass with 34 to $66 \mathrm{~cm}$ seasonal rainfall ${ }^{42}$ and similar high yields have been observed across the US. ${ }^{43}$ Irrigated corn (a similar C4 crop) in Nebraska has had average aboveground dry biomass yields of $20.3 \mathrm{Mg} \mathrm{ha}^{-1} \mathrm{yr}^{-1}$ from 2001 to $2008 .^{59}$ These measurements suggest SS could have similar and better yields across the Corn Belt and eastern US by 2050 as estimated above. FT-biodiesel from SS would require slightly more land, 15.1 Mha (11.7\%).

* 303.6 Mha of US forest land in 2009. ${ }^{56}$

With increasing transportation efficiency, biofuels can contribute to a greater fraction of fuel use, such as in Brazil in 2010 where ethanol was $54 \%$ of the gasoline market $(25 \%$ gasoline blend plus hydrated ethanol $^{50}$ ) and used only $7 \%$ of agricultural land (Table 1 ). Recent extensive analysis suggests revolutionary energy efficiency improvements (including vehicle fuel efficiency at 125-240 mpg) could reduce US oil demand for all transportation modes by $84 \%$ by $2050 .{ }^{49}$ Increasing US fuel efficiency has already begun with the 2012 CAFE standards that mandate an increase in vehicle efficiency from 35.5 to $54.5 \mathrm{mpg}$ from 2016 to 2025 . Annual demand by 2050 could require only 254 billion liters of biofuel to sustain all US transportation, and grown on only $11 \%$ of agricultural land for sweet sorghum or $15 \%$ of forest land for short rotation hardwood (Table 2). Alternatively, 6\% of agricultural land and 7\% of forest land could be used, but in either scenario, less crop land would be needed for biofuels than used today. These biofuels would provide 6.9 EJ of energy, which is roughly 300 times the amount of energy needed annually to power the Mongol empire.

If society is to be more dependent on bioenergy resources, the total size of global human population should also be limited by all humane methods. ${ }^{51}$ With increasing population, limited energy resources will eventually only support a high quality of life for a declining few. ${ }^{15}$ Energy use at 50 gigajoules per capita per year, or 1.6 kilowatts per capita, is associated with longer lifespans and higher human development indices, which is slightly more energy than used on average in India and China in 2003. ${ }^{1}$ Recent analysis suggests that better coordination in agriculture and forestry can improve food security, increase bioenergy, and reduce net greenhouse gas emissions, largely by reducing meat consumption which increases the efficiency of the food system in some cases. ${ }^{41}$
From an overview of recent developments in thermodynamics, it is clear that complexity is not infinitely abundant, nor does it arise without a thermodynamic cost. In the future, society has potential to develop an electrified economy dominated by transformations of solar radiation (including wind) with access to greater than four orders-of-magnitude more free energy than used today from all energy sources, ${ }^{1}$ yet the speed of this transition is slow due to underdeveloped technology for electricity storage, high infrastructure costs, and societal inertia. But in a future economy where fossil fuels are no longer used because of climate change, deeply ingrained ecological processes ensure that biofuels will be the last carbon-based fuel to be made obsolete for human transportation.

Acknowledgments - This research was supported by the Institute of Agriculture and Natural Resources (University of Nebraska-Lincoln), the George Dempster Smith Chair of Industrial Ecology (A.L.), and the UCARE scholars program (C.H.). Professors Richard Perrin and Bruce Dale provided many helpful comments and suggestions.

\section{References}

1. Smil V, Energy in Nature and Society: The Energetics of Complex Systems. MIT Press, Cambridge, MA (2008).

2. Smil V, Harvesting the Biosphere: What We Have Taken from Nature. MIT Press, Cambridge, MA (2013).

3. Liska AJ and Perrin RK, Securing foreign oil: A case for including military in the climate change impact of fuels. Environment 52:9-22 (2010).

4. Karl TR, Melillo JM and Peterson TC, eds., Climate Change Impacts in the United States. Cambridge University Press, New York (2009). 
5. Naylor RL, Liska AJ, Burke MB, Falcon WP, Gaskell J, Rozelle SD and Cassman KG, The ripple effect: Biofuels, food security, and the environment. Environment 49:30-43 (2007).

6. Prigogine I and Stengers I, Order Out of Chaos: Man's New Dialogue with Nature. Bantam, New York (1984).

7. Atkins PW, Four Laws that Drive the Universe. Oxford University Press, New York (2007).

8. Chaisson EJ, Cosmic Evolution: The Rise of Complexity in $\mathrm{Na}$ ture. Harvard University Press, Cambridge, MA (2001).

9. Kauffman S, At Home in the Universe: The Search for the Laws of Self-Organization and Complexity. Oxford University Press, New York (1995).

10. Samimy M, Breuer KS, Leal LG and Steen PH, A Gallery of Fluid Motion. Cambridge University Press, New York (2003).

11. Blundell SJ and Blundell KM. Concepts in Thermal Physics, Second Edition. Oxford University Press, New York, NY, USA (2010).

12. Bakshi BR, Gutowski TG and Sekulić DP, eds., Thermodynamics and the Destruction of Resources. Cambridge University Press, Cambridge, MA, USA (2011).

13. Mitchell M, Complexity: A Guided Tour. Oxford University Press, New York, NY (2009).

14. Morris SC, Life's Solution: Inevitable Humans in a Lonely Universe. Cambridge University Press, New York, NY, USA (2003).

15. Colinvaux PA, Why Big Fierce Animals Are Rare: An Ecologist's Perspective. Princeton University Press, Princeton, NJ, USA (1978).

16. Bennett D, Conquerors: The Roots of New World Horsemanship. Amigo Publications, Los Alamos, CA, USA (1998).

17. Emsley J, Nature's Building Blocks: An A-Z Guide to the Elements. Oxford University Press, New York, NY, USA (2003).

18. Atkins PW and De Paula J, Physical Chemistry, 9th edn. W. H. Freeman (2009).

19. Christian D, Maps of Time: An Introduction to Big History. University of California Press, Berkeley, CA, USA (2005).

20. Haberl $H$, The energetic metabolism of societies: Part II: Empirical examples. J Ind Ecol 5:71-88 (2001).

21. Costanza R, Graumlich LJ and Steffen W (eds), Sustainability or Collapse? An Integrated History and Future of People on Earth. MIT Press, Cambridge, MA, USA (2007).

22. Ryder OA, A horse of a different chromosome? Nat Hist 103:54-57 (1996).

23. Kelekna $\mathrm{P}$, The Horse in Human History. Cambridge University Press, New York (2009).

24. Phillips K, American Theocracy: The Peril and Politics of Radical Religion, Oil, and Barrowed Money in the 21st Century. Penguin, New York, NY, USA (2006)

25. Fouquet $R$ and Pearson PJG, $A$ thousand years of energy use in the United Kingdom. Energy J 19:1-41 (1999).

26. Energy Information Administration, Annual Energy Review 2010. US Department of Energy (2011).

27. Radler M, Worldwide oil production steady in 2011; reported reserves grow. Oil Gas J 109:26-28 (2011).

28. World Bank, A Citizen's Guide to National Oil Companies: Part A, Technical Report. World Bank, Washington DC, USA (2008).
29. Aleklett $K$, Höök M, Jakobsson $K$, Lardelli $M$, Snowden $S$ and Söderbergh B, The peak of the oil age-Analyzing the world oil production reference scenario in World Energy Outlook 2008. Energ Policy 38:1398-1414 (2010).

30. Tverberg GE, Oil supply limits and the continuing financial crisis. Energy 37:27-34 (2012).

31. Bosello F, Carraro C and De Cian E, Market- and policydriven adapation, in Smart Solution to Climate Change: Comparing Costs and Benefits, ed by Lomborg B. Cambridge University Press, New York, NY, USA (2010).

32. Hall SJG, The horse in human society, in The Domestic Horse: The Evolution, Development, and Management of its Behaviour, ed by Mills D and McDonnell S. Cambridge University Press, New York, NY, USA (2005).

33. Millennium Ecosystem Assessment, Ecosystems and Human Well-Being, vol 1, Current State and Trends. Island Press, Washington DC, USA (2005).

34. Feller W, An Introduction to Probability Theory and its Applications, vol 1, 3rd edn. John Wiley \& Sons, New York, NY, USA (1968).

35. Gott JR, Implications of the Copernican principle for our future prospects. Nature 363:315-319 (1993).

36. Gott JR, Time Travel in Einstein's Universe. Houghton Mifflin, New York, NY, USA (2001).

37. Silver N, The Signal and the Noise: Why So Many Predictions Fail-But Some Don't. Penguin, New York, NY, USA (2012).

38. Running SW, A measureable planetary boundary for the biosphere. Science 337:1458-1459 (2012).

39. Fargione J, Plevin RJ and Hill J, The ecological impact of biofuels. Annu Rev Ecol Evol Syst 41:351-77 (2010).

40. Brown RC, Biorenewable Resources: Engineering New Products from Agriculture. Blackwell, Ames, IA, USA (2003).

41. Smith P, Haberl H, Popp A, Erb K, Lauk C, Harper R et al., How much land based greenhouse gas mitigation can be achieved without compromising food security and environmental goals? Glob Chang Biol doi: 10.1111/gcb.12160 (2013).

42. Wortmann CS, Liska AJ, Ferguson RB, Klein RN, Lyon DJ and Dweikat I, Dryland performance of sweet sorghum and grain crops for biofuel in Nebraska. Agron J 102:319-326 (2010).

43. Wortmann CS and Regassa T, Sweet sorghum as a bioenergy crop for the US Great Plains, in Economic Effects of Biofuel Production, ed by dos Santos Bernardes MA. InTech, Croatia (2011).

44. Raffa KF, Aukema BH, Bentz BJ, Carroll AL, Hicke JA, Turner MG and Romme $\mathrm{WH}$, Cross-scale drivers of natural disturbances prone to anthropogenic amplification: Dynamics of biome-wide bark beetle eruptions. Bioscience 58:501-518 (2008).

45. National Academy of Science, America's Energy Future: Technology and Transformation. NAS, Washington DC, USA (2010).

46. Cullen JM, Allwood JM, and Borgstein EH, Reducing energy demand: What are the practical limits? Environ Sci Technol 45:1711-1718 (2011).

47. Barrow JD, Impossibility: The Limits of Science and the Science of Limits. Oxford University Press, New York, NY, USA (1998). 
48. Wuppertal Institute for Climate, Environment, and Energy, Sustainable Urban Infrastructure; Munich Edition-Path to a Carbon-Free Future. WICEE, Berlin, Germany (2009).

49. Lovins $A B$ and Rocky Mountain Institute, Reinventing Fire: Bold Business Solutions for a New Energy Era. Chelsea Green, White River Junction, VT (2011).

50. US Department of Agriculture Foreign Agricultural Service, Brazil Biofuels Annual 2010. Gain Report BR10006. Washington DC, USA (2010).

51. Connelly M, Fatal Misconception: The Struggle to Control World Population. Harvard University Press, Cambridge, MA, USA (2008).

52. Cong Y, Baker ML, Jakana J, Woolford D, Miller EJ, Reissmann $S$ et al., 4.0-A resolution cryo-EM structure of the mammalian chaperonin TRiC/CCT reveals its unique subunit arrangement. P Natl Acad Sci USA 107:4967-4972 (2010).

53. Chambers J, The Devil's Horsemen: The Mongol Invasion of Europe. Book Sales, Minneapolis, MN, USA (2003).

54. Boxer CM, The Dutch economic decline, in The Economic Decline of Empires, ed by Cipolla CM. Methuen \& Co Ltd, London, UK (1970).

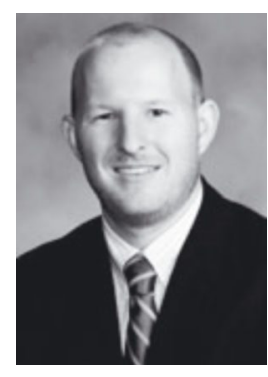

\section{Adam J. Liska}

Adam Liska is an Assistant Professor and the George Dempster Smith Chair of Industrial Ecology in Biological Systems Engineering and Agronomy \& Horticulture at the University of Nebraska. He completed a PhD in Biology at the Max Planck Institute of Molecular Cell Biology and Genetics in Dresden, Germany in 2003, and currently teaches Energy Science.
55. US Department of Agriculture National Agricultural Statistics Service, Crop Production 2010 Summary, Cr Pr 2-1 (11)a. Washington DC, USA (2011).

56. Food and Agriculture Organization of the United Nations (FAOSTAT). Online at: http://faostat.fao.org/ [October 8, 2012].

57. Fachagentur Nachwachsende Rohstoffe, Tabelle der Anbaufläche für nachwachsende Rohstoffe. Online at: http://mediathek.fnr.de/grafiken/daten-und-fakten/anbauflache-furnachwachsende-rohstoffe-2012-tabelle.html [September 25, 2012].

58. Cherubini F and Stroemman AH, Production of biofuels and biochemicals from lignocellulosic biomass: Estimation of maximum theoretical yields and efficiencies using matrix algebra. Energ Fuel 24:2657-2666 (2010).

59. Grassini $P$, Thorburn J, Burr $C$ and Cassman KG, High-yield irrigated maize in the Western U.S. corn belt: I. On-farm yield, yield potential, and impact of agronomic practices. Field Crop Res 120:142-150 (2011).

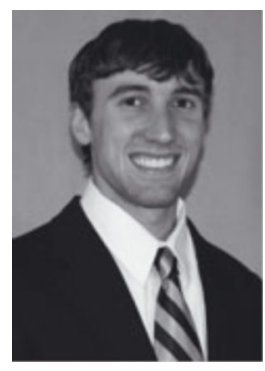

\section{Casey D. Heier}

Casey Heier is co-founder and Operations Director for The World Energy Project. Casey earned a BSc in Biological Systems Engineering from the University of Nebraska in May 2013 and will pursue his MSc at Stanford University in the Atmosphere/Energy program within the Department of Civil \& Environmental Engineering. 